\title{
KINERJA PEGAWAI DI TERMINAL KAYU MANGIWANG KABUPATEN MAMUJU TENGAH
}

\author{
Sri Ms. ${ }^{1}$, Djuliyati Saleh ${ }^{2}$, Nurbiah Tahir ${ }^{3}$ \\ ${ }^{1)}$ Mahasiswa, Jurusan Ilmu Administasi Negara Unismuh Makassar \\ 2) Dosen, Jurusan Ilmu Administasi Negara Unismuh Makassar \\ 3) Dosen, Jurusan Ilmu Administasi Negara Unismuh Makassar
}

\begin{abstract}
ABSTRAK
Job Performance or achievement is a job or effort achieved by a person in carrying the duty assigned to him/her, based on the skill, quality, experience, willingness and time. The type of the research used is qualitative descriptive approach involving 10 informants such as Head of Department, Secretary, Head of Sub Division of Staffing and General, Head of Sub Division of Planning and Finance, Field of Traffic and Transportation, Vehicle Driver. The data were collected through interview and observation method.The results of this research reveal that the performance of the employees in Termina Kayu Mangiwang of Central Mamuju Regency has been optimal. It can be identified from the factors that affect the performance of the ability and motivation that significantly affect the performance of employees. The indicators of objectives, qualitative, quantitative,.
\end{abstract}

Key word: Performance, employee,station

\begin{abstract}
ABSTRAK
Kinerja atau prestasi kerja merupakan suatu kerja atau/usahayang dicapai seseorang dalam melaksanakan tugas yang dibebankan kepadanya, yang didasarkan atas kecakapan, kualitas, pengalaman, dan kesungguhan serta waktu..Jenis penelitian menggunakan pendekatan deskriptif kualitatif dengan pedoman informan yaitu Kepala Dinas, sekertaris, kepala sub bagian kepegwaian dan umum, kepala sub bagian perencanaan dan keuangan, bidang lalu lintas dan angkutan, pengemudi kendaraan. Dengan metode wawancara dan observasi.Hasil penelitian yang diperoleh dalam penelitian iniadalah bahwa Kinerja Pegawai Di Terminal Kayu Mangiwang Kabupaten Mamuju Tengah sudah cukup baik. Hal itu dapat dilihat dari faktor yang mempengaruhi kinerja yaitu kemampuan dan motivasi yang berpengaruh secara signifikan terhadap kinerja pegawai. Indikator tujuan, kualitatif, kuantitatif.
\end{abstract}

Kata Kunci : kinerja, karyawan, terminal 


\section{PENDAHULUAN}

Kinerja atau prestasi kerja murupakan hasil yang terukur dicapai oleh individu atau organisasi dalam pelaksanaan tugas pokok dan fungsinya. Pengukuran kinerja adalah suatu action yang dilakukan oleh individu untuk melaksanakan kegiatan atau menjalankan tugas guna keberhasilan dalam organisasi (pegawai) dalam mencapai misinya. pelayanan publik sangat dibutuhkan dalam menilai seberapa jauh pelayanan yang telah diberikan oleh organisasi pemerintah, Melakukan penilaian suatu kinerja maka upaya untuk merenovasi sebuah kinerja dapat dilakukan lebih terarah dan sistematis.

Armstrong dan Baron (1998:15) menyatakan bahwa kinerja adalah merupakan hasil pekerjaan yang mempunyai hubungan kuat dengan tujuan strategi organisasi,

kepuasaan, konsumen dan memberikan kontribusi pada ekonomi, kemudian Mahsun (2013:25) menyatakan bahwa kinerja adalah bayangan mengenai tingkat pencapaian pelaksanaan suatu kegiatan /program/kebijakan dalam menemukan suatu sasaran, tujuan, misi dan visi organisasi yang berada didalam strategik planning suatu organisasi. Dengan demikian kinerja adalah tentang melakukan sebuah action dan hasil yang dicapai dengan pekerjaan tersebut, Kinerja dalam suatu organisasi senantiasa diupayakan dalam peningkatannya karena dalam meningkatkan kinerja tidak saja akan membawa pengaruh langsung kepada suatu organisasi, namun akan berdampak terhadap peningkatan kemampuan pegawai.

Pegawai merupakan aset utama dalam suatu organisasi, sebagai langkah pergerakan kelangsungan hidup suatu organisasi, Keberhasilan dalam mencapai suatu tujuannya sangat tergantung pada kinerja pegawai Dalam rangka mengantisipasi persaingan yang semakin ketat, diperlukan suatu program pengembangan pegawai sesuai dengan tingkat dinamika dan tuntutan kebutuhan bagi pelaksananaan tugas-tugas organisasi pelayanan publik. Kemampuan pegawai dalam pelayanan publik dapat memiliki kinerja yang efektif. Pembangunan nasional yang 
dilaksanakan di negara berkembang ini. Sehingga dapat untuk memberikan pelayanan kepada masyrakat sesuai dengan tuntutan pembangunan itu sendri Kemudian hal itu dijelaskan pula dalam Undang-Undang No 25 tahun 2009 bahwa seorang pelayan publik untuk memncukupi sebuah kebutuhan, pelayanan harus sesuai aturan dan dapat memakmurkan Negara dan Daerah Pembangunan daerah, apalagi daerah baru berkembang hal ini menjadi sebagai bagian penting dari pembangunan nasional maka seluruh pegawai yang bertugas di Terminal Kayu Mangiwang Kabupaten Mamuju Tengah dituntut untuk memiliki kinerja yang tinggi, suatu organisasi harus mempunyai standar untuk bekerja sehingga dapat mengetahui kapan visi dan misi dapat tercapai dan terselesaikan dengan baik.

\section{Soedaryono}

pengertian pegawai adalah seseorang yang melakukan penghidupannya dengan bekerja dalam suatu organisasi, baik organisasi publik maupun swasta. Jadi, Pegawai bukan hanya hanya dibutuhkan sebagai pemenuh kebutuhan organisasi masa kini tetapi juga untuk memenuhi dinamika organisasi sebagai akibat perubahan lingkungan.

Pegawai yang berkualitas adalah pegawai yang memiliki kecakapan dan kemampuan untuk melaksanakan berbagai tugas yang diberikan kepadanya dengan baik, serta mampu memenuhi dan

mengembangkna kecakapan, kemampuannya secara teratur dan berkembang melalui pendidikan dan pelatihan Kinerja pegawai merupakan indikator keberhasilan organisasi dan sangat dipengaruhi oleh kemampuan dan motifasi kerja dan manusia tersebut. Kinerja pegawai di Terminal Kayu Mangiwang Kabupaten Mamuju Tengah pada awal berdirinya

Terminal Kayu Mangiwang masyarakat sudah antusias untuk melakukan sarana atau prasarana yang disediakan di Terminal baik melakukan perjalanan transportasi, pembelian tiket kendaraan, dan tempat untuk beristirahat bagi pengguna kendaraan keberadaannya dapat meringankan ataupun mempermudah masyarakat untuk 


\begin{tabular}{lrr} 
melakukan & \multicolumn{1}{c}{ aktifitas } & yang \\
berhubungan dengan & Terminal \\
Ditunjang dengan kinerja & pegawai \\
pada saat itu masih & sangat \\
berantusias untuk bekerja & sesuai \\
dengan prosedur yang telah & pada masing-masing \\
ditetapkan pan & \\
jabatan.
\end{tabular}

Undang-Undang No 22 tahun 2009 tentang lalulintas dan angkutan jalan mempunyai tugastugas pokok sesuai bidangnya masing-masing yang berperan penting dalam baik buruknya

Terminal Kayu Mangiwang tergantung pada kinerja pegawai

Dinas Perhubungan dalam menjalankan tugas dan fungsinya

\section{Gomes}

mengemukakan defenisi kinerja karyawan sebagai "ungkapan seperti output efesiensi serta efektifitas sering dihubungkan dengan produktivitas." Selanjutnya, defenisi kinerja karyawan menurut Mangkunegara (2000:67) bahwa “ kinerja karyawan (prestasi kerja) adalah hasil kerja secara kualitas dan kuantitas yang didapatkan oleh seorang karyawan dalam menjalankan tugasnya sesuai dengan tanggung jawab yang dipikulnya,

Wibowo

(Amstrong

Dan

Baron,1998:15) menyatakan bahwa performance sering diartikan sebagai kinerja, hasil kerja atau prestasi kinerja Kinerja adalah tentang melakukan pekerjaan dan hasil yang dicapai dari pekerjaan tersebut. Kinerja adalah tentang apa yang dikerjakan dan bagimana cara mengerjakannya. Kinerja meupakan hasil pekerjaaan yang mempunyai hubungan kuat dengan tujuan strategi organisasi, kepuasan konsumen dan memberikan kontribusi ekonomi,

Indikator kinerja adalah, ukuran kuantitatif dan atau kualitatif yang menggambarkan tingkat pencapaian suatu sasaran atau tujuan Sementara menurut Lohman (2003:25) indikator kinerja (performance indicators) adalah suatu variabel yang digunakan untuk mengekspresikan secara kuantitatif efektivitas dan efesiensi proses atau oprasi dengan berpedoman pada target-target dan tujuan organisasi.

Mangkunegara

mengemukukakan bahwa kinerja 
adalah suatu hasil sebuah kinerja secara kualitas dan kuantitas yang dicapai oleh seorang pegawai dalam melaksanakan tugasnya sesuai dengan tanggung jawab yang diberikan padanya. (1) kualitas adalah patokan utama yang harus dicapai, kualitas adalah melakukan hal secara benar, bagaimanan cara mencapai visi dan sasaran yang bermutu. kualitas adalah semua sifat suatu jasa atau pelayanan yang dapat mempengaruhi pada sebuah kemampuannya untuk memuaskan kebutuhan yang individu. kualitas adalah titik fokus untuk menegaskan dan menilai hal-hal baik atau hal-hal buruk dalam berbagai hal atau dalam berbagai peristiwa yang selalu berhubungan dengan melakukan hal secara baik, bagaimanan cara mencapai sebuah sasaran yang bermutu serta efisiensi. (2) kuantitas adalah tolak ukur dari sebuah kinerja yang dapat dinyatakan dalam angka. Kuantitas kerja ini dapat dilihat dari kecepatan kerja setiap pegewai itu masing-masing. Kuantitas adalah sbentuk satuan ukur, sebuah hasil kerja, dan dinyatakan dalam ukuran angka. "Quantity" (kualitas) adalah segala bentuk satuan ukuran yang terkait dengan jumlah, hasil kerja, dan dinyatakan dalam ukuran angka atau yang dapat dipandankan dengan angka. (3) Pelaksanaan tugas dalam Administrasi Negara pejabat yang menempati posisi jabatan yang tertinggi untuk melaksanakan sebuah amanahnya dan memiliki bakat untuk melaksanakan tugasnya guna tercapainya tujuan yang telah di tentukan sebelumnya. Pelaksanaan tugas adalah seberapa jauh karyawan dapat melakukan pekerjaannya dengan target atau tidak ada kesalahan. Baik dalam instansi publik maupun instansi swasta, pelaksanaan tugas diartikan sebagai dorongan atau kegiatan yang sudah terencana dan dilakukan oleh pegawai dalam memenuhi tuntutan dari jabatan atau pimpinannya. (3) tanggung jawab adalah sikap dan prilaku seseorang untuk melaksanakan tugas dan kwajibannya sebagai mana yang seharusnya dilakukan terhadap diri sendiri, dan lingkungan ( alam , sosial, dan budaya), negara dan tuhan.(4) Tanggung jawab adalah merupakan kesadaran manusia 
sebagai perwujudan kesadaran akan kewajiban. Tanggung jawab bersifat kodrati, yang artinya tanggung jawab itu sudah menjadi bagian kehidupan manusia, Tanggung jawab terhadap pekerjaan adalah keharusan, kewajiban pegawai untuk melakukan pekerjaan yang diberikan atasannya.

Wibowo (2007:7) manajemen kinerja adalah manajemen tentang menciptakan hubungan dan memastikan komunikasi yang efektif. Manajemen kinerja memfokuskan pada apa yang dilakukan oleh organisasi, manajer, dan pekerja untuk berhasil. Amstrong Dan Boron (1998:7) berpandang bahwa manajemen kinerja adalah pendekatan strategis dan terpadu untuk menyampaikan sukses berkelanjutan pada organisasi dengan memperbaiki kinerja karyawan yang bekerja didalamnya dan dengan mengembangkan kapabilitas tim dan kontributor individu Upaya meningkatkan kinerja pegawai dalam memenuhi tuntutan organisasi maka manajemen kinerja (performance management) perlu mendapat perhatian yang besar dari aparatur negara. (a) Pengukuran Kinerja, (b)
Klasifikasi Ukuran Kerja, (c) ketepatan waktu, (d) Siklus Waktu, (e) pemanfaatan sumber daya manusia, (f) Biaya.

Faktor-faktor yang mempengaruhi kinerja sebagaimana yang dikemukakan oleh Keith Davis dalam buku Mangkunegara (2000:67). (a) Faktor Kemampuan (Ability) Individu untuk mengerjakan berbagai tugas dalam suatu pekerjaan tidak sama satu dengan yang lainnya. Setiap manusia mempunyai kemampuan berfikir. Kemampuan (ability) merupakan kecakapan seseorang (kecerdasan dan keterampilan) dalam memecahkan persoalan. (b) Faktor Motifasi (Motivation) Motifasi diartikan sebagai suatu sikap (atitude) pimpinan dan karyawan terhadap situasi kerja Jeral Greenberg Dan Robert A. Baron (2003:190) berpendapat bahwa motivasi adalah serangkaianprosesyang membangkitkan(arouse), mengarahkan(maintain) prilaku manusia menuju pada pencapaian tujuan.

Soedaryono dalam bukunya (2000:6) pengertian pegawai adalah 
"seseorang yang melakukan penghidupannya dengan bekerja dalam kesatuan organisasi, baik kesatuan kerja pemerintah maupun kesatuan kerja swasta, pengertian pegawai adalah orang pribadi yang bekerja pada pemberi kerja, baik sebagai pegawai tetap atau tidak, berdasarkan kesepakatan kerja yang baik tertulis maupun tidak tertulis, untuk melaksanakan suatu pekerjaan dalam jabatan atau kegiatan yang ditetapkan oleh pemberi pekerja. Pegawai tetap adalah pegawai yang tepat dan tetap menerima penghasilannya dalam waktu yang tetap. Peran pegawai Terminal Kayu Mangiwang adalah Dinas Perhunbungan. Peran Dinas Perhubungan dalam lalu lintas sesuai UU No 22 tahun 2009 tentang lalu lintas dan angkatan jalan mempunyai tugas-tugas pokok sesuai bidangnya antara lain : (1) Bidang lalu lintas,

(2) Bidang sarana dan prasarana, (3)

Bidang oprasional. Fungsi pegawai

di Terminal Kayu Mangiwang: 1 .

Kebijakan pelayanan teknis Dinas

Perhubungan.(2)Penyelenggaraan

pengawasan,(3) Pelaksaan utama di bidang peroprasian kendaraan (4) elaksanaan tugas lainnya yang diberikan oleh Bupati.

\section{METODE PENELITIAN}

Penelitian ini akan berlangsung selama 2 bulan januari sampai dengan maret 2018 setelah seminar proposal. Tempat atau lokasi penelitian ini dilakukan di Terminal Kayu Mangiwang Kabupaten Mamuju Tengah, realita empirik di balik fenomena secara mendalam, rinci dan tuntas. Penelitian ini berusaha menjelaskan sedetail mungkin objek dan masalah penelitian berdasarkan fakta yang diperoleh dilapangan. Sugiyono (2014), metode kualitatif juga disebut metode artistik, karena penelitian lebih bersifat seni (kurang terpola) dan metode interpretive karena data hasil penelitian interpretasinya terhadap data yang ditemukan di lapangan. Tipe penelitian yang digunakan peneliti adalah pendekatan fenomenologi yakni suatu bentuk penelitian yang menekankan pada subyektivitas pengalaman hidup manusia untuk mengungkapkan kejadian atau fakta, fenomena, dan keadaan yang terjadi saat penelitian berlangsung. Sumber 
data yang digunakan adalah sumber data adalah Data primer, data ini adalah data yang didapatkan melalui hasil wawancara dan observasi di

Terminal Kayu Mangiwang Kabupaten Mamuju Tengah dan Data skunder, adalah data yang

dikumpulkan peneliti yang sumbernya berasal dari data-data sebelumnya menjadi seperangkat informasi dalam bentuk dokumen, laporan-laporan, dan informasi tertulis.

Informan dalam penelitian ini ditetapkan secara puposive sampling, berdasarkan pertimbangan yaitu kinerja pegawai di Terminal Kayu Mangiwang Kabupaten Mamuju Tengah dalam penelitian ini agar mendapat data yang akurat dan akuntabel. Berdasarkan proses pemilihan tersebut, kemudian dipilih informan sebagai berikut : Kepala Dinas Perhubungan Kabupaten Mamuju Tengah, Sekertaris Dinas Perhubungan Kabupaten Mamuju Tengah, Kepala Sub Bagian Kepegawaian Dan Umum, Kepala Sub Bagian Perencanaan Dan Keuangan, Bidang Lalu Lintas Dan
Angkutan, Dan Pengemudi Kendaraan.

Pengumpulan data dalam penelitian ini dilakukan beberapa cara yaitu (1) Observasi dilakukan dengan mengamati (2) Wawancara yaitu teknik pengumpulan data dengan melakukan wawancara untuk mendapatkan informasi,

Dokument asi yaitu teknik pengumpulan data yang dilakukan untuk menyediakan dokumendokumen.

\section{HASIL DAN PEMBAHASAN}

berdasarkan dengan tujuan penelitian ini yang tercantum dari bab sebelumnya, untuk mengetahui bagaimana kinerja pegawai di

Terminal Kayu Mangiwang Kabupaten Mamuju Tengah adapun indikator kinerja yaitu : kualitas, kuantitas, pelaksanaaan tugas, dan pertanggung jawaban dan faktor yang mempengarui kinerja adalah kemampuan dan motivasi

kualitas yang dimaksud disini adalah merupakan mutu, melakukan hal secara benar, bagaimana dalam mencapai sebuah sasaran, bermutu 
dan efisiensi. Dan bagaimana dalam instansi publik untuk menjalankan kualitas nya baik dalam sebuah kinerja individu, kelompok dan organisasi untuk menunjang organisasi tersebut. pada kualitas ini yang menjadi point utama adalah kinerja pegawai yang kurang berkualitas sehingga membuat terminal menjadi kurang beroprasi secara baik, benar dan berkualitas sesuai aturan ataupun visi misi yang telah ditentukan sebelumnya, kualitas adalah semua sifat suatu jasa atau pelayanan yang dapat mempengaruhi pada sebuah kemampuannya untuk memuaskan kebutuhan yang individu. jadi kualitas adalah titik fokus untuk menegaskan dan menilai hal-hal baik atau hal-hal buruk dalam berbagai hal atau dalam berbagai peristiwa

kuantitas yang dimaksud disini adalah tolak ukur dari sebuah kinerja yang dapat dinyatakan dalam angka. Kuantitas kerja ini dapat dilihat dari kecepatan kerja setiap pegewai itu masing-masing. Kuantitas adalah sbentuk satuan ukur, sebuah hasil kerja, dan dinyatakan dalam ukuran angka Quantityof work (kuantitas kerja) adalah jumlah kerja yang dilaksanakan oleh seseorang pegawai dalam suatu priode tertentu. jadi kualitas kualitas kerja seorang pegawai dapat dilihat dari trik menggunakan waktu dan kecepatan sebuah kinerjanya. kemudian pelaksanaan tugas dari pegawai terminal kayu mangiwang adalah visi

misi itu sendiri dan pertanggungjawaban pegawai terminal kayu mangiwag adalah pelaksanaan tugas dari visi dan misi yang baik berkualitas, bermutu dan kuantitas yang dapat diukur dalam satuan angka.

Visi dan misi Terminal Kayu Mangiwang Kabupaten Mamuju Tengah di kedudukan oleh pengelolah terminal yang dimana

pengelola Terminal Kayu Mangiwang Kabupaten Mamuju Tengah adalah Dinas Perhubungan Kabupaten Mamuju Tengah yaitu sebagai berikut :

Visi dinas perhubungan bersama masyarakat menuju transportasi yang terpadu, 
berkelanjutan, berorientasi global, dan ramah lingkungan bernuansa pemerintahan yang bersih dan profesional. Gelobal adalah mendunia, dimana Terminal Kayu Mangiwang dapat bersaing dengan terminal-terminal lainnya yang telah maju dan berkembang, mengikuti kinerja yang baik dan berkualitas, Ramah lingkungan bernuansa pemerintahan yang bersih dan profesional, pebangunan yang diharapkan dapat terlaksanakan secara cepat, tepat, jujur, akuntabel dan transparan ditangan pemimpin yang cakap dibidang transportasi. Kemudian transportasi yang terpadu adalah mengupayakan sistem peningkatan pelayanan , pengawasan dan penjualan karcis secara mudah dan dapat meningkatkan kemudahan kepada masyarakat untuk mengakses transfortasi, Berkelanjutan atau pembangunan berkelanjutan adalah pembangunan yang memenuhi kebutuhan sekarang tanpa harus mengorbankan pemenuhan kebutuhan generasi masa depan.
Selanjutnya misi Dinas Perhubungan Di Kabupaten Mamuju Tengah adalah sebagai berikut :

(1)Mewujudkan sarana transportasi yang aman, handal, ramah

lingkungan dan terjangkau masyarakat, (2) Mewujudkan

prasarana transportasi yang berkualitas dan memiliki standar nasional dan internasional, meningkatkan kenyamanan dan keselamatan, (3) Meningkatkan aksesibilitas masyarakat terhadap pelayanan jasa perhubungan, dan (4) Meningkatkan manajemen transportasi perkotaan yang mudah di aksesmelalui jaringan transportasi terpadu.

Kepala Dinas Perhubungan sebagai unsur pemerintah kabupaten bertanggung jawab kepada Bupati Mamuju Tengah dalam pelaksanaan tugas pemerintah dan pelayanan dibidan transportasi dan perhubungan. Untuk melakukan tugas sebagaimana dimaksud dalam pasal 5 huruf D angka 15 ayat (1), Dinas Perhubungan mempunyai fungsi sebagai berikut : (1)Perumusan kebijakan penyelenggara urusan pemerintah 
dibidang perhubungan, (2)

Pelaksanaan kebijakan urusan pemerintahan bidang perhubungan,

(3) Pelaksanaan evaluasi dan pelaporan urusan pemerintah dibidang perhubungan, dan

Pelaksanaan administrasi dinas

urusan pemerintah bidang

perhubungan.

Sekretaris mempunyai tugas

mengkoordinasi

kegiatan,

memberikan pelayanan teknis dan administrasi urusan umum dan kepegawaian Untuk melaksanakan tugas sebagaimana di atas, sekertaris mempunyai fungsi sebagai berikut.

Mengkoordinasi pelayanan kegiatan.(2) Mengelola urusan umum, administrasi kepegawaian dan umum. Pengelola administrasi keuangan, (3) Pengelola dan penyusunan program serta pengelolahan dan penyajian data ,(4) Pengelolahan dan pembinaan organisasi dan tatalaksana, Pelaksanaan tugas lain yang diberikan oleh atasan sesuai dengan tugas dan fungsinya. kepala sub bagian perencanaan dan keuangan memiliki fungsi sebagai berikut:

(1)Penyusunan rencana pelaksanaan tugas sub bagian perencanaan dan keuangan,(2) Pelaksanan penyusunan rencana program/ kegiatandan anggaran dinas sumber dana apbd,(3) Pelaksana pengelola keuangan dinas sumber dana APBD. kepala sub bagian kepegawaian dan umum memiliki fungsi sebagai berikut: (1) Penyusunan rencana pelaksnaan tugas sub bagian kepegawaian dan umum, (2) Pengelola administrasi

persuratan kepegawaian dan pengelola kearsipan. (3) Pengelola administrasi kepegawaian, (4)

pelaksana administrasi.

Pencatatanaset dan barang milik negara maupun daerah. (5)

Pendokumentasian pelaksanaan acara-acara dinas.

Kepala bidang lalu lintas dan angkutan jalan memiliki fungsi sebagai berikut: (1) Penyiapan barang perumusan kebijakan dibidang lalu lintas jalan, angkutan dan terminal, (2) Penyiapan bahan pelaksanaan kebijakan dalam rangka peningkatan eksesbilitasdan konektifitas lalu lintas dan angkutan jalan, (3) Penyiapan bahan pelaksana kebijakan dan pembinaan serta fasilitasi urusan dibidang-dibidang 
lalu lintas jalan ,angkutan jalan dan terminal. (4)Penyiapan data dan informasi, (5) Mengikuti rapat teknis terkait bidang yang bersangkutan. Bidang prasarana dan keselamatan:

(1) Penyiapan Bahan rencana program pemantauan dan analisis kerja oprasional prasarana jalan dan perkeretaapian. (2) Penyusunan bahan rencana program usulan peningkatan kaapasitas jalan, terminal dan kebutuhan lalu lintas,

(3) Penyiapan, penyusunan dan evaluasi bahan kebijakan pelaksanaan penyelenggaraan audit keselamatan jalan, inspeksi lalu lintas jalan serta analisis dampak lalu lintas, (4) Penyiapan perumusan bahan rencana program perbaikan lokasi potensi kecelakaan dan kemacetan lalu lintas dan jalan di provinsi, Penyusunan bahan kebijakan pedoman dan standar teknis pelaksana keselamatan, dan

(5) Penyiapan penyusunan bahan rencana program peningkatan sarana lalu lintas angkutan jalan.

Keadaan pegawai di terminal kayu mangiwang kabupaten mamuju tengah terbagi atas 3 bagan yang dimana bagan tersebut, (1) pangkat dan golongan pegawai di terminal dapat dilihat sebagai berikut : golongan 4 sebanyak 10\%, golongan 3 sebanyak 40\%, golongan 2 sebanyak $10 \%$ dan golongan 4 sebanyak 40\%. (2) berdasarkan tingkat pendidikan golongan golongan IV berjumlah 7orang dengan tingkat pendiddikn masingmasing s1 sebanyak 2 orang, dan s2 sebanyak 5 orang, golongan III berjumlah 15 orang pegawai negri sipil dengan tingkat masing-masing DII sebanyak 1 orang, s1 sebanyak 13 orang dan s2 sebanyak 1 orang pegawai. golongan II berjumlah 5 orang pegawai dengan tingkat pendidikan S1sebanyak 5 orang dan golongan 1 berjumlah 20 orang pegawai, dengan tingkat masingmasing D1 sebanyak 3 orang dan S1 sebanyak 17 orang pegawai. (3) berdasarkan tingkat eselon tingkat eselon IVA sebanyak 1 orang dan IVB sebanyak 6 orang pegawai, sedangkan IIIA sebanyak o orang dan IIIB sebanyak 15 orang pegawai, sedangkan pegawai eselon II sebanyak 2 orang pegawai dan eselon I sebanyak 20 orang pegawai negeri sipil. 
Kualitas didalam sebuah kinerja yang baik, para pegawai harus menjalankan tugasnya sesuai dengan kemampuan yang mereka miliki dan pemimpin mempunyai peran penting untuk mengkoordinasi , mengarahkan dan memiliki kemampuan mempengaruhi dan menggerakkan para bawahannya untuk bekerja mencapai sebuah tujuan yang berkualitas, efektif, efisien dan bermutu agar mencapai tujuan sasaran organisasi. dalam sebuah organisasi, kepemimpinan memegang peran yang sangat penting, pemimpin harus dapat mempengaruhi dan menggerakkan bawahannya agar mecapai kinerja yang berkualitas dan bermutu, yaitu suatu semangat kerja yang maksimal. dalam mencapai tujuan organisasi seperti apa yang diharapkan maka sangat dibutuhkan suatu gaya kepemimpinan yang sesuai visi dan misi organisasi.

kualitas juga merupakan suatu keadaan yang harus dijadikan patokan agar mendapatkan kinerja yang baik di masa yang akan datang. kualitas juga merupakan arah dalam suatukinerjayangharus terselesaikan sesuai target. dan dari itu dilakukan kinerja yang efektif agar mencapai tujuan kinerja yang berkualitas. untuk mencapai tujuan. Diperlukan kinerja yang berkualitas baik dalam individu dan kelompok. kinerja individu maupun kelompok dikatakan berhasil apabila mencapai tujuan secara berkualitas sesuai dengan target dan bermutu.

Menetapakan tujuan kinerja sangat perlu dalam organisasi akan tetapi tak hanya tujuan yang ingin dicapai, akan tetapi bagaimana kinerja nya dapat tercapai secara berkualitas. baik dalam proses manajemen yang memastikan bahwa setiap pegawai tahu peran apa yang harus mereka lakukan dan hasil apa yang harus mereka capai dalam setiap organisasi

Setiap suatu organisasi memiliki satuan ukur yang dapat diukur baik dari sebuah pendapat ataupun kinerja individu, dalam

Terminal Kayu Mangiwang Kabupaten Mamuju Tengah, beberapa informan menyebutkan bahwa dalam penjualan karcis kendaraaan diwajibkan untuk membayar iuran sebesar Rp 3000 
dan hal ini tetap diterapkan di terminal sepanjang peroprasian normal, dan dalam penjualan karcis kendaraan hal itu tidak menyulitkan sama sekali sebagian pengemudi karna dianggap wajar dan tetap pada aturan yang dimana dalam menunjang prekonomian daerah, daerah sendiri memiliki daya guna BUMN yang dimana digunakan untuk memudahkan dan melayani masyarakat agah lebih baik dan sejahtra kemudian kinerja dapat dilihat dengan prestasi kerja yang dapat diukur melalui kemampuan dalam menjalankan tugasnya sebagai pelayan publik.

BUMN adalah badan usaha milik negara guna menunjang perekonomian negara, dalam hal ini BUMN didirikan negara dalam instansi pemerintah berbentuk pelayanan guna menciptakan kemudahan masyarakat dalam berbagai bidang termasuk salah Satunya Terminal Kayu Mangiwang itu sendiri. dan betul terminal tersebut dapat memudahkan masyarakat luas baik masyarakat mamuju tengah maupun diluar mamuju tengah yang beroprasi diterminal tersebut. Sehingga tidak sedikit masyarakat ataupun pengemudi dan penumpang merasa lebih puas dan merasa mudah untuk melakukan sebuah perjalanan, dan hal ini tentu dapat dilihat dari Kinerja Pegawai Terminal Kayu Mangiwang Kabupaten Mamuju Tengah, sebuah kinerja dapat dilihat dari kenyamanan dan kepuasan masyarakat hal itu sudah menjadi tolak ukur sebuah kinerja jadi Kinerja Pegawai Terminal Kayu Mangiwang Kabupaten Mamuju Tengah kuantitas kinerja nya dapat dilihat melalui kepuasan dan kenyamanan masyarakat.

Pegawai memiliki jabatan dan wewenang yang berbeda-beda dan setiap jabatan yang dipegang memiliki tugas yang berbeda-beda sehingga informan selaku pegawai di staf melakukan kinerjanya secara sesuai wewenang dan pegawai harus dapat menjalankan hak dan kwajibannya dalam melaksanakan tugas, fungsinya, dan kwajibannya. Tugasnya di masing-masing bidang dan jabatannya seperti yang telah di tetapkan dalam organisasi di Dinas Perhubungan Kabupaten Mamuju 
Tengah, Dengan demikian pegawai harus lebih terarah dan tepat pada sasaran ya telah ditetapkan.

bagaimana pegawai bisa melakukannya sesuai yang telah diembankan kepadanya dengan pertanggungjawaban sebagai seorang pegawai haruslah dapat melakukan hal secara benar dan haruslah dapat melaksanakan tugasnya sesuai apa yang telah diberikannya terutama kecepatanannya sebagai seorang pegawai bagaimana pegawai tersebut cepat, cekat dan teratur untuk hasil kerja pegawai yang baik dan berkalitas sehingga dapat memajukan jalannya sebuah perusahaan atau organisasi yang dijalankannya. hal ini dapat dilihat dari pelaksanaan tugas karena kunci utama dari sebuah organisasi adalah manusiannya dan kinerjannya hal yang utama yang dapat dilihat dari majunya organisasi adlah kinerjanya pegawai yang dimana melaksanakan tugas sesuai pekerjaan yang dibebankan padanya.

Sehingga pelaksanaan tugas dari pegawai sangat berperan penting untuk kemajuan organisasi dan didalam Terminal Kayu Mangiwang lebih baik dari sebelumnya
Pegawai

memang diwajibkan memiliki tangggungjawab atas jabtan yang dikendalikannya, termasuk dalam mengendalikan antara hak dan kewaiban antara hak dan wewenang, semua seorang pegawai baik dari skala kecil maupun skala besar memiliki hak dan tanggungjawab bergantung pada jabatan nya semakin tinggi jenjang hirarki atau wewenangnya semakin tinggi

pertanggungjawabannya dalam kinerja, oleh sebab itu seorang pegawai dituntut untuk terus bekerja sesuai prosedur dan wewenangnya, tidak dengan haknya saja karena sebuah kualitas yang baik dalam pegawai tergantung bagaimana cara dia menjalankan tugasnya dan sebuah kualitas yang bagus ada seorang kepala organisasi yang menjalankannya oleh sebab itu harus seimbang nya hak dan kewajbna harus seimbang antra tugas dan tanggung jawabnya

Kemampuan atau ability seseorang tidak lain adalah potensi yang dimiliki oleh seseorang untuk melakukan dan menyelesaikan pekerjaan. Seseorang pegawai dapat 
mencapai hasil yang memuaskan dalam bekerja tergantung dari kemampuan dan kecakapannya. dan tidak lepas dari beberapa yang memang harus diperhatikan bagaimana seorang pegawai harus cerdik dalam melakukan tugasnya agar tercapai pada target sasaran organisasi, dari beberpa pegawai yang penulis wawancarai adapun pegawai yang tidak menempatkan jabatan dengan pendidikan karna faktor kekurangan tenaga kerja hal itu sekaligus dapat menghambat dan sedikit menunjang kinerja. akan tetapi para pegawai di Dnas Perhubungan dan Terminal Kayu Mangiwang Mamuju Tengah tetap berusaha mengedepankan kwalitas skinerja yang baik.

\section{Motivasi} sangat berpengaruh penting dalam meningkatkan kualitas kinerja pegawai. Karena apabila pegawai pegawai mempunyai motivasi untuk mencapai tujuan pribadinya, maka mereka harus meningkatkan kinerja . meningkatkan kinerjanya maka akan meningkat pula kinerja organisasinya. Dengan demikian, meningkatnya motivasi pegawai akan meningkatkan kinerja individu, kelompok, maupun organisasi. maka dari itu perlunya sebuah penghargaan dengan peluang pendidikan, seperti pelatihan, menghadiri konprensi, diklat-diklat, yang memungkinkan mereka mempertahankan bidangnya.

Motivasi adalah suatu hasrat atau keinginan yang timbul pada diri seseorang untuk melakukan tindakan-tindakan dalam mencapai target atau hasil yang diharapkan. Seorang pegawai dapat termotivasi dengan membandingkan kinerjanya dengan kinerja pegawai yang lainnya yang lebih berprestasi sehingga muncul dorongan untuk lebih berprestari dari pegawai yang berprestasi tersebut, karena seseorang berprilaku tertentu di dorong oleh berbagai macam kebutuhan yang harus dipenuhi.

\section{KESIMPULAN}

Berdasarkan hasil penelitian mengenai kinerja pegawai di Dinas Perhubungan Kabupaten Mamuju Tengah Dan Terminal Kayu 
Mangiwang maka dirumuskan kesimpulan sebagai berikut:

kinerja pegawai di dinas perhubungan kabupaten mamuju tengah sudah efektif melihat kualitas dan kuantitas yang ingin dicapai. para pegawai betu-betul bekerja dengan sangat maksimal sehingga dapat memenuhi standar SOP yang ada didinas perhubungan. faktor yang mempengaruhi kinerja pegawai diterminal kayu mangiwang kabupaten mamuju tengah, pegawai lebih giat dan gigih dalam melaksanakan tugas yang meraka jabati dibidang masing-masing tepat waktu dan berkualitaspegawai sangat. termotifasi dengan apa yang diberikan oleh atasan mereka seperti promosi jabatan, kenaikan pangkat dan penghargaan lainnya

\section{DAFTAR PUSTAKA}

Amstrong Dan Baron, A. 1998.

Performance Manajement-

The New Realities. London:

Institude Of Personnel

Development

Gomes, 1995. Manajemen Sumber Daya Manusia. Yogyakarta: Penerbit Andi.

Lohman, 2003. Tersedia Online Mohmahsun.

Blogspot.Com/2017/09/Indikat or Kinerja

Mangkunegara, A, 2002. Manajement Sumber Daya Manusia, Bandung: PT Remaja Rosdakarya.

Mangkunegara, A 2000. Manajemen Sumber Daya Perusahaan, Bandung: PT Remaja Rosdakarya.

Mangkunegara, A 2009. Manajemen Sumber Daya Manusia. Bandung: PT Remaja Rosda Karya

Mahsun, Mohamad, 2013. Pengukuran Kinerja Sektor Publik, Yogyakarta: BpfeYogyakarta.

Sugiyono,2012. Memahami Penelitian Kualitatif. Bandung; Alfabeta.

Wibowo, 2007. Manajemen Kinerja. Jakarta: Pt Rajagrafindo Persada.

Wibowo 2012, manajemen kinerja edisi ketiga, jakarta: PT rajagrafindo persada. 
Undang-Undang No. 22 Tahun 2009.

Tentang Lalu Lintas Dan

Angkutan Jalan. Bandung:

Citra Umbara.

Undang-Undang No. 25 Tahun 2009.

Tentang Pelayanan Publik.

Bandung: Citra Umbara

Soedaryono, 2000. Pengertian pegawai

(http.//pengertianpegawai.haki msimanjuntak.com/2017/0/23/.

html) diakses jam 23:40. 2017 